\title{
A Case Study of Higher Education in Mongolia:
}

\section{Institutional Isomorphism}

\author{
Dembereldorj Zoljargal $^{1}$ \\ ${ }^{1}$ Center for Foreign languages, Division of Humanities, School of Arts and Sciences, National University of \\ Mongolia, Mongolia \\ Correspondence: Dembereldorj Zoljargal, Center for Foreign languages, Division of Humanities, School of Arts and \\ Sciences, National University of Mongolia, Ikh surguuliin gudamj-1 P.O.Box - 46A/523, 210646 Ulaanbaatar, \\ Mongolia. E-mail: zoljargald@ num.edu.mn
}

Received: October 21, 2019

Accepted: November 22, 2019

Online Published: November 23, 2019

doi:10.5430/ijhe.v9n1p107

URL: https://doi.org/10.5430/ijhe.v9n1p107

\begin{abstract}
Universities elsewhere have been changing its purposes, functions, roles, and pursuits in society. This study is a case study of Mongolian higher education in which institutional changes are taking place incrementally. The purpose of this study is to explore institutional isomorphism or homogenization of a case university in Mongolia in two different periods of which one is a university under the Soviet regime in the past, and the other is under the democracy in present. The research question was how a university in Mongolia has been changing isomorphically under the different environmental pressures. The study applied a single case study proposed by Yin $(2003 ; 2009)$ to explore homogenization or isomorphic changes at one prestigious higher education institution in Mongolia. Interviews, reports, and other related documents were used for the analysis. The analytical procedure applied main elements of qualitative research methods. The findings are discussed in three major themes: coercive isomorphism of a university, isomorphic changes triggered by the faculty members: bottom-up process, and mimetic isomorphism modeling after American higher education. It is concluded that the institutional changes taken place in the university was first pressured by the coercion dictated by the political social circumstances, that is, Soviet regime; second, by the faculty members triggered by the professionalization; and third, by the mimicry modeling after successful higher education institution, an American higher education system.
\end{abstract}

Keywords: higher education, Mongolia, isomorphism, rankings, institutional changes

\section{Introduction}

Nowadays, higher education is in constant flux. Scholars documented that the changing nature of higher education institutions has been induced by the world university rankings. Hazelkorn (2009) identified changing actions in research, changes in organizational structure, a curriculum that bridges the EU and US model, target doctoral students, and internationalization, hire talented scholars and changes in management and marketing of higher education institutions. With the comparative analysis of higher education institutions of Australia, Japan, and Germany, the author concluded that despite context differences - political regime, history, mission, and geography there are remarkable similarities between how different types of institutions in Germany, Australia, and Japan are responding, the decisions they are making and the reasons why (Hazelkorn, 2009).

Many institutions across the globe claim that they plan to become world-class universities by a certain date or that they have already achieved this status (Birnbaum, 2007). The phenomenon of building a "world-class university" is evident in countries such as China, South Korea, Malaysia, Taiwan, Denmark, and Finland. For instance, Finland reformed its higher education system by merging 20 universities into 15 to 16 universities. The purpose of this action is to build a "world-class university" with the account of improving the efficiency and effectiveness of higher education institutions in Finland. The reforms, however, will lead to increased autonomy for universities, which will be afforded legal status in their own right, and will have much increased financial freedom (Aarrevaara, et. al., 2009). In Asia, for instance, the Chinese government has put an immense effort to build a "world-class university" by implementing policies such as the "985 scheme." It aimed at building a "world-class university" in China and has begun its implementation since 1999. With the implementation of the 985 Scheme in 1999, Peking and Tsinghua universities both received 1.8 billion yuan (US\$225 million) in the first round of special 985 funding within three 
successive years from 1999 (Ngok \& Guo, 2008). The government and higher education institutions both implement the strategies to build and become a "world-class university."

With regard to changes in higher education, the Korean government has been implementing two major streams of projects: one is to recruit international students and the other is to internationalize higher education institutions with prominent scholars from abroad (Byun \& Kim, 2011; Jon, Lee \& Byun, 2014). At an institutional level, Kim and Nam (2007) discussed how Seoul National University has been changing and upgrading the university in response to university rankings. The university shifted its doctoral program requirements with more comprehensive examinations and graduate courses similar to the US system. It began to encourage faculty members to publish articles in internationally acclaimed journals for the tenure review process as well as the consideration of new hires (Kim \& Nam, 2007). Moreover, it started promoting more global connections through faculty and joint degrees with foreign higher education institutions. As a result, such changes and reform policies have improved the overall institutional performance. Arimoto (2011) identified that South Korea has placed the first (average research productivity was 36.0) in their research productivity in comparison with Japan, Italy, China, and Germany.

There is a vivid isomorphic process in higher education induced mainly by the world university rankings. King (2010) discussed that global league tables are significantly influencing national policymaking and local higher education institutions around the world. League tables are a key part of university environment in all developed societies even though only the relatively few worldwide rankings for the top universities are global in scope and comparisons (King, 2010:5). The competitive purposes of rankings tend to induce a homogeneous and isomorphic profile of universities and to reinforce the ever-present modeling effect of research universities on other categories of universities (Proulx, 2007). Marginson (2002) argued that governments and institutions are all too readily drawn into isomorphism, that is, strategies of mimicry. Dembereldorj (2018) viewed that global university rankings shape higher education institutions to build competitive capability for being-ranked institutions, and build institutional capability for willing-to-be-ranked institutions. These scholars imply that isomorphism is essential to examine the homogenization of higher education institutions.

Mongolian higher education institutions have been hit by the wave of world higher education reforms to emphasize research in higher education and the knowledge economy. At the government level, policy pursuits in higher education induced by the world university rankings are directed to improve human resource capacity by supporting Mongolian students to study abroad. Mongolian students who are enrolled in 20 top-ranked universities in world university rankings are eligible to receive funding from the government (http://www.meds.gov.mn/post130826). There are few government initiatives to implement strategies to build a "world-class university" or similarly reform higher education as other countries.

Institutional mergers became common to achieve organizational scale and to absorb academically weaker institutions within larger units (Balan, 2006:293). In 2010, the Mongolian government passed the bill to restructure the Mongolian higher education system into a more manageable way and differentiate the role and mission of the higher education system. For instance, the University of Ulaanbaatar, Institute of Commerce and Business and Institute of Customs and Economics were merged into the National University of Mongolia from 1 July 2010. However, some universities were reluctant and withdrawn from the mergers. This step of structure-based reform is considered to enhance the quality of higher education, to allocate funding efficiently such as building a new campus for the national universities. This top-down reform in the Mongolian higher education system can be considered as the initial step to reform higher education institutions and further to equip them to build a "world-class university."

Even though there is not much support from the government to build a research-intensive "world-class university," a few state higher education institutions attempt to change themselves at the organizational level to catch up with the global trend of higher education. The National University of Mongolia is an example of an incremental change to adopt and model after the higher education institutions identified in the top of world university rankings. The university was teaching dominated and more oriented to prepare human resources to society. Recently, the university has been shifting itself into building a research-intensive university. The university has been changing its administrative pattern into corporate governance system modeling after the American model of research universities by eliminating the former Soviet Union governance system. There have been numerous seminars and conferences at the National University of Mongolia on how to build a research university and its challenges. Observing these phenomena of building a research university by modeling after the top-ranked universities have prompted to conduct a research for better understanding some of the processes of institutional changes of a university in Mongolia.

Based on the previous literature and the observation of the changes in Mongolian higher education institutions, the study explores institutional isomorphism or homogenization of a university in Mongolia in two different periods of 
which one is a university under the Soviet regime in the past, and the other is under the democracy in present. The research question is how a university in Mongolia has been changing isomorphically under different environmental pressures.

\section{Theoretical Framework}

This study applies the neo-institutional theory of isomorphism as its theoretical lens. It explains institutional changes that affect one institution to become similar to others. It can help to explore the homogenization process of a Mongolian higher education institution.

The process of homogenization is isomorphism (DiMaggio \& Powell, 1983), the process of organizations becoming similar or homogenous. Once disparate organizations in the same line of business are structured into an actual field (by competition, the state or the professions), powerful forces emerge that lead them to become more similar to one another (DiMaggio \& Powell, 1983). One of the field powerful forces can be viewed as world university rankings which are shaping current higher education systems elsewhere. Likewise, during the Soviet regime, almost all sectors in Mongolia were shaped by the Soviet system. Thus, the theory of isomorphism provides a plausible framework to explore the current research question.

There are three isomorphic mechanisms: coercive that stems from political influence and the problem of legitimacy; mimetic isomorphism resulting from standard responses to uncertainty; and normative isomorphism, associated with professionalization (DiMaggio \& Powell, 1983). Here, we can view that a case university in Mongolia was established under the Soviet regime and its changes or reforms had been shaped by the socio-political condition of the country.

Coercive isomorphism can be formal or informal pressure that influence organizations by technical and exchange interdependence. Formal pressure is policies, regulations, and standards issued by the administration and the government. Informal pressure can be cultural expectations and norms that make the organization submissive to the environment.

Mimetic process is one way of modeling the organizations which are perceived to be successful and legitimate. Models may be diffused unintentionally, indirectly through employee transfer or turnover, or explicitly by organizations such as consulting firms or industry trade associations (DiMaggio \& Powell, 1983). Because models are observable in an organization, it can be easily modeled by other organizations.

Uncertainty is central in the mimetic process. Uncertainty can be characterized as unclear technology, ambiguous goal and symbolic uncertainty in the environment. Clark (1983) defined that institutions of higher education are seen as preeminent examples of loosely coupled organized systems in which ambiguity results from soft technologies, fragmented work, and participants who wander in and out, as well as from vague goals (Clark, 1983). With this uncertainty, universities elsewhere have been imitating the universities that are perceived to be the authority or those ranked at the top.

Normative pressure is the third source of isomorphism that stems from professionalization (DiMaggio \& Powell, 1983). There are two aspects of professionalization: formal education which staffs are educated in the higher education institutions and professional networks that can contribute to the diffusion of new models.

\section{Research Design: Single Case Study}

This study applies a single-case study approach. The single case is one of the prestigious higher education institutions in Mongolia. The case study is appropriate for this study for two reasons.

First, Yin $(2003$; 2009) stated that it is important to identify the type of research question being asked. With the research question in this study, it is exploratory and investigative. Yin (2003) recommended that it is favorable to use a case study when we ask what, how and why. This study explores how a university has been changing isomorphically in two different periods: the Soviet regime and democracy.

Second, it helps understand the effects of the environmental pressures on one university in Mongolia embedded with its past and current context. It is relevant to the definition of a case study that it is an empirical inquiry that investigates a contemporary phenomenon in depth and within its real-life context, especially when the boundaries between phenomenon and context are not clearly evident (Yin, 2003; 2009).

The strength of the case study should be acknowledged here. George and Bennett (2005) discussed that there are four strong strengths of case studies: they are potential for achieving higher conceptual validity; they are strong procedures for fostering new hypotheses; their value as a useful means to closely examine the hypothesized role of causal mechanisms in the context of individual cases; and their capacity for addressing causal complexity. 


\subsection{Data Collection}

There are two kinds of data sources: institutional documents, policy documents and reports; and interviews with university administrators and faculty members. Variation of documents and interviews can help to enhance the validity and reliability of the study.

The documents collected for this study consist of any available policy documents, regulations of the institution from the government, annual reports, university magazines, and history books. In addition to these documents, internet sources will supplement it.

Interviews were conducted with university administrators and faculty members. The purposive sampling was determined based on the organizational structure of the target institution. Interviewees selected from each unit of the organization can provide us with views, changes, experiences of their representing units. The interviewees agreed to be interviewed by signing on consent forms. Three of the selected administrators declined to give interviews. The study collected 15 interviewees of which 14 is audiotaped and transcribed, and 1 is interviewed without audiotaping. The interviews mainly concerned with university reforms. The interview employed semi-structured questions about their views and experiences related to the purpose of the research. It lasted about 30-50 minutes.

\subsection{Analytical Procedure}

There are two main procedures of data analysis. The first data analysis was documents such as university history books, annual reports, policy documents, regulations, internet sources and so on. It employed the technique of content analysis. The second data analysis is the interview. It employed open and axial coding procedure proposed by Corbin \& Strauss (1990).

Both analyses began by exploring the main environmental pressures on the case university. After identifying pressures at an institutional level, the researcher explored how they were and are shaping the institution isomorphically to imitate other institutions. The researcher examined the changes of isomorphism in the institution by beginning with the theoretical proposition. Theoretical propositions are the most preferred strategy (Yin, 2009). Drawing from these analytical procedures, the study reports the findings according to three major themes.

\section{Findings}

\subsection{Coercive Isomorphism of the University}

The current National University of Mongolia was established in 1942 with an initiative of Marshal Choibalsan. It is the first higher education institution in Mongolia to prepare human resources with higher education in the country. There are two main environmental demands to establish the university in Mongolia. One of the university presidents, Sodnom (2003) argued that the country needed to "refill" its intelligent human resources who could have the ability to work at an administrative positions of the country. Due to the genocide that killed many intelligent elites, leading professionals in academic fields, political leaders as well as many innocent people, the country was left without intelligent leaders and professionals in the late 1930s.

In order to develop and run the country, Mongolia urged to have intelligent administrative staffs and professionals in key sectors such as agriculture, industry, medical care, zoology, education and engineering. There was a societal demand to establish a university that produce and prepare professionals with higher education in the field of politics of the country, socio-economic fields, arts and education (Boldbaatar, J. et al., 2002). Hence, the Committee of the People's Ministries passed the decree No. 45 on 6 December 1940 to establish a university in Ulaanbaatar and commence the academic year beginning from 1 September 1941. The first rector (Note 1) of the university was Mashlai, T, who was a minister of the Ministry of People's Education.

The university was established with three faculties: medical science, zoology and pedagogy. The first students attended remedial courses that can pursue post-secondary study in the above fields. These students were from both Mongolian secondary schools and Russian secondary schools. After a year of remedial courses, on 6 October 1942, the university commenced its courses enrolling 92 students (Sodnom, 2003). The courses were provided in Russian language by specially invited Russian professors who were the leading scholars at that time. For instance, Professor and Doctor of Chemistry, S. I. Khromov, Professor and Doctor of Physics and Mathematics, A.G. Shafigulin, Professor and Doctor of Mathematics, I. B. Veitsman, Professor and Doctor of Medical Science, V.N.-Topolisky. These professors also headed the three faculties and served as chairs.

Since that time, the university has expanded in terms of organizational structure, human resources, facilities and enrollments. Liguu (1971) documented that as of 1972, the National University of Mongolia held 39 departments with 2358 students and 318 faculty members. The facilities were also increasing and improving as the university 
expanded. For instance, in 1947, it opened a faculty of social sciences with majors of economics and history; in 1958, geology class; in 1961, extensive or evening classes; in 1969 faculty of mechanics and engineering and so on. These are the few examples of such expansion of the university. Based on the three foundation faculties, the current state university of agriculture, state university of medical science and state university of education were established. The State University of Education was established in 1951 whereas the State University of Agriculture was established in 1958 and the State University of Medical Science in 1961 respectively (Boldbaatar, et al., 2002). This shows that the university expanded enormously that these three major faculties were able to operate at the level of an independent university.

Faculty members in the university were developing both research and teaching. The number of Mongolian instructors increased, and eventually, Russian instructors and administrative staffs were replaced by Mongolian faculty members. According to the university rector's decree No. 84 of 5 July 1946, the first excellent graduates of the university in 1946 were left in the university to work as assistants for the departments. For instance, Sandagiin Sosorbaram, Puntsagiin Shinjee, and Namsrain Sodnom. Besides these faculty members, there are many other part-time faculty members from the Academy of Science, Central Committee of the Mongolian People's Revolutionary Party and State ministries.

The National University of Mongolia was fully regulated by and dependent on the government till 1990s. The government during the communist period issued 5-year plans which determined the education policy basis: the first one is 1948-1952; the second one 1953-1957 and the third 1961-1965. The university regulations and rules were based on the decree approved by the chair of Committee for Higher and Professional Education under the Commission of the Government Ministries (Purevdulam, 2005). For instance, the regulation indicated that "the Committee for Higher and Professional Education, which is the state central organization for education affairs, appoints all administrative staffs - the rector, prorector (Note 2) for supply and resources, prorector for research and prorector for pedagogy; the rector has absolute power to run and regulate the university and its functions (Purevdulam, 2005). There is another example of a regulation dictated by the government in 1962 that was applied to all higher education institutions in Mongolia. The regulation designated the pedagogical forms of the courses: 1. Lecture; 2. Laboratory work and practical seminar; 3. Industrial practicum; 4. Course practicum outside the classroom; 5. Course projects; 6. Diploma work; 7. Course guidance; 8. On class and off class examination; and 9. Student independent work (Shagdar, 2008:418). These forms mirrored all the structure, administration, curriculum and research of the Soviet Union higher education system.

The university modeled after the higher education system of the Soviet Union. For this, the state of Mongolia had been playing a crucial role. As a part of the decree issued from the Commission of the ministries, the central committee of the Mongolian People's Revolutionary Party in December of 1972 to improve and sophisticate the higher education system, the university began to develop the curriculum, lesson plans and syllabi similar with the higher education institutions in the Soviet Union. During the 1970-1980s the university paid much effort to improve the quality of its pedagogical aspects and intensified Russian language training in the university. All major courses were taught in Russian language (Boldbaatar, et al., 2002). Besides Russian language, the curriculum in the field of social sciences was characterized by the propaganda to instill the students with Marxist and Communist thoughts. It was well documented by Shagdar (2008) that the bureau of politics of the Central Commission of the Mongolian People's Revolutionary Party issued a decree to provide the courses such as "A theory of scientific communism," "A theory of Marxism and Leninism," "A history of the Communist Party of the Soviet Union," "Marxist-Leninist Philosophy" and the like. The author noted that the decree was a crucial document after the decree of 1946 and 1949 to strengthen the pedagogical aspects with communist political ideas and thoughts and propagandize them through education. These evidences show that the National University of Mongolia was heavily concentrated to the teaching aspects and played a major role to prepare human resources with respect to the socio-political demands and dictated by the government with all respects.

One explanation of its teaching orientation can be the higher education system that had imitated Russian higher education system in which the main research was conducted by a special organization called Academy of Science. Nevertheless, the university faculty members conducted their research and worked with close association with the Academy of Science of Mongolia. Sodnom, (2003) documented that the first academic journal of the university was "Scientific Letters" published in Russian language in 1946. Between 1944-1945 the university held academic conferences among Russian faculty members and Mongolian students. Probably this has continued till today's so-called "Students' research seminar" as an annual seminar at the university. Even though it is not numerically measureable to what extent or how much of the university functions of research and teaching weight more than the 
other, Mongolian scholars agree that the university has been more teaching oriented and the pedagogical contents have been tilted to provide theoretical and fundamental science knowledge.

During the Soviet Union period, the university had played a crucial role in building social classes. It produced most of the members in the working class of intelligence. This class was a new social class in Mongolia. Liguu (1971) defined the class of intelligence or a person of intelligence (in Russian "intelligentsia") is a person with specific higher education who runs "brain work." The class of intelligence consisted of those who completed a higher education and specialized in specific majors such as doctors, teachers, public and state officials. The university did not only produce professionals with higher education to serve in the social and industrial areas, but also prepared future scholars. In 1949, the university opened asperantura which is equal to an educational level of graduate school of our time. The purpose was to prepare university instructors and researchers. The first scholars prepared by the National University of Mongolia graduated in early 1950s.

Academic degrees in the university were similar to the Soviet Union academic degrees in higher education system. In 1945, the Commission of the state ministries issued a decree to identify the degree of faculty members. There were two levels of scholar's degree for scientific workers for their contribution to the science and their research work: first, Candidate of Science and second, Doctor of Science. There were three levels of scholar's degree for scientific workers for their contribution in both science through research and pedagogy through teaching: first, assistant, second, dotsent (similar with associate) and third, professor. The faculty members were awarded with these scholar's degrees but the job position was all faculty members. Sodnom (2003) noted that this scholar's degree system was adopted through the Soviet Union from the Central Europe.

The historical perspective of the National University of Mongolia leads to the following conclusion. The university was heavily influenced by its environmental socio-political and economic factors during its development period. As a satellite country for the Soviet Union till 1990s, Mongolian political communist and social regime shaped the entire university in terms of organizational structure, regulation, rules of conducts, content of the curriculum, academic degree levels, administration and missions mainly imitating a higher education system of the Soviet Union. This was necessary at the political level to adopt Soviet higher education system as it was perceived as legitimate system to imitate in the context of the communist and socialist political regime.

One of the main economic factors that shaped the university during this time was the demand to prepare and produce necessary human resources and provide the country with capable, intelligent human capacity. As discussed above, it was meant to prepare Mongolian human resources or intelligent industrial and academic workers for further development of the country. Hence, the main mission of the National University of Mongolia was oriented towards the teaching and pedagogy.

Due to the fact that the state was imperative at every dimension of the society, the university had a limited opportunity to develop itself. The socio-political condition did not allow the institution to make changes on its own and, therefore, the centrally orchestrated institutional environment influenced the university behavior till 1990s.

\subsection{Isomorphic Changes Triggered by the Faculty Members: Bottom-up Process}

During the democratization and free marketization process of the society, the university has not made significant reforms until the 2010s. The reforms first were initiated by the instructors and faculty members to improve the efficiency of the institution as well as to join the mainstream of the world higher education trends. The initial step of the reforms was a structural change within the organization. It included changes at the school as well as the departmental level by merging departments relative to their field of research and teaching. For instance, in the academic year of 2012-2013, the university was functioning with 14 schools - School of Mathematics and Computer Science, School of Physics and Electronics, School of Biotechnology and Biology, School of Mongolian Language and Culture, School of Social Science, School of Economics, School of Chemistry and Chemical Engineering, School of Geology and geography, School of Law, School of International Relations, School of Foreign Languages and Culture, School of Information Technology, School of Trade (previously state-funded university merged into the university), Ulaanbataar School (previously state-funded university merged into the university), Orkhon School (a provincial branch school of the university), and Zavkhan School (a provincial branch school of the university). These schools were rearranged to become five schools next academic year, 2013-2014: School of Science and Arts with subdivision of natural science, social science, and humanity, School of Applied Science, Business school, Law School as well as School of International Relations and Public Administration. The departments of the schools were also rearranged into larger departments. 
According to the interviews, the purpose of the structural changes was to establish a structure that the principles of a world-class higher education system can function efficiently. One interviewee mentioned that to build a world-class or world standard university the structural changes make the principles of current world higher education trends work, the university imitated the American model of higher education, particularly Stanford University. By imitating the American model of the higher education system, the university opted to follow the educational tradition of liberal arts at the bachelor level. Another interviewee viewed that such departmental level of structural changes can improve efficiency, and facilitate interdisciplinary research and collaboration among faculty members. The structural changes were predicted to provide infrastructure for liberal arts education at the bachelor level for the students and interdisciplinary research among faculty members. Thus, the university began its major reforms by imitating the American model of the higher education system with the initiation of faculty members.

Faculty members who studied abroad were working with faculty members in foreign countries, and bringing the culture of collaborative research work. Those research works were mainly funded by foreign institutions. One of the interviewees mentioned that the abroad educated faculty members have become the main human resource of the university. Another interviewee also noted that individual scholars or faculty members of the university generally take initiatives to introduce the newest trends and approaches in the field such as meeting the world standards of nanotechnology. It was documented in the report of 2013-2014 that number of faculty members have been contributing to its field of research, building their school of science due to their commitment and initiatives to build their laboratories and research environment, and publish their studies in internationally acknowledged journals. Such efforts were not sufficiently supported by the state budget. These statements and interviews illustrate that the faculty members were playing the main role in bringing about institutional changes in their working environment. Eventually, the university has begun to intensify its research collaboration as well as research activities.

\subsection{Mimetic Isomorphism Modeling after American Higher Education}

Beginning from the 2013-2014 academic year, the institution formulated a goal of becoming a research university to meet the standards of the world-class universities. The structural changes imitating after the American model of universities such as Stanford University have started to serve its infrastructure to build a research university. A concept of research university has been mentioned in the reports and policy documents.

The university has started to promote researching and improve research facilities at the university. To build research capacity, the university made an official request to the Ministry of Education and Science. As reported, seven main laboratories were funded from the ministry in the academic year of 2013-2014, and six laboratories of basic research were funded from the project of "Higher education reform" run by the Asian Development Bank.

Besides, the university developed strategic plans for 2016-2020 to build a research university by encouraging faculty members who constantly conduct research and introducing research management actions at the university. One of the actions was to promote the professorial team encouraging more involvement of graduate students in the projects. Many of the grants provided by the university started to require graduate student involvement in the proposed projects. Concerning research promotion, the university has begun to implement various grants to support the research activities of the faculty members and foster international as well as domestic collaborations. In 2016, the university introduced five types of grants especially for the faculty members with a doctoral degree: a grant for basic expenses of the research, a grant for young researchers' team, a research stipend for visiting professors or researchers, seed grants for collaborative research with international scholars, and funding for advanced studies to publish JCR impact factor journals. As a result, research-related activities such as funding, laboratories have intensified, as shown in the reports, from 118 in 2013-2014 academic year to 240 in 2015-2016.

Since the 2017-2018 academic year, the university has begun to pursue world-class university to be ranked in the top 100 of the Asian university rankings. To achieve the goal, the university emphasized, first, to increase research capacity and meet the world standard, and second, bring teaching and learning to the world standard level. The university has started to emphasize the increase of number in faculty members with doctoral degrees and the number of publications in Thomson's Reuter's indexed journals.

Resembling the American model of higher education, the university has been implementing activities to promote university-industry collaborations and start-up companies. The report of academic year 2016-2017 documents that the university administrators held meetings with major business organizations such as "Teso" LLC, "MAK" LLC, "Vitafit" LLC and "Gachtuurt" LLC to exchange ideas and further collaborate in the field of biotechnology, coal chemistry, and pure energy technology. Moreover, a forum "University-Industry Collaboration and Development" was held in December 2017 to reflect private sectors "needs and opinions for future technological studies, to find possibilities to realize research findings onto the practice and to intensify local collaboration with other industries. 
The notion of entrepreneurial university, university-industry collaborations as well as start-up companies is foreign to the institution, let alone younger generation of faculty members. Thus, the previously teaching-oriented, state-dependent, Soviet model of the university has turned to the model after American higher education tradition.

Another tradition modeled after American higher education is the establishment of the student affairs office. The university created the office in the academic year of 2016-2017 to support students with the following aspects: student academic orientation, provide students with scholarships, dormitory services, exchange student programs, services for health, sports and culture, support for international students, services to support student employment, guidance for student institutions, services for handicap students, and collaboration with graduates as well as other institutions. It was reported that the following academic year, the student service improved activities such as dormitory accessibility, students' clubs, and service for handicapped students. Student affairs is relatively a new entity as an office entitled to support students as such office was not present in the university administration, and the student issues were handled solely by the respective school academic affairs administration.

As a consequence, the university is in its incremental changes attempting to join the mainstream higher education trends. Recent institutional changes indicate that the university is modeling after the American higher education system as the evidence above shows. The institutional changes have been initiated by the faculty members which is the bottom-up process or the professionalization pressure of isomorphic institutional changes. The process is also incremental as the institutional changes begin with institutional restructuring, reformulating the university focus to be researching than teaching, taking after the elements of the American universities such as start-up companies as well as collaboration with industries, improving research facilities, and promoting professorial research teamwork. The university is putting efforts to meet the world standards of higher education. It is viewed by the interviewers and policymakers that the American higher education model is worth to imitate to be integrated into the world-class higher education.

\section{Conclusion}

The case study of one higher education institution explores how it has changed isomorphically under two different institutional environments: Soviet regime and period of democracy. The study implies that the university has changed incrementally, first, under the coercion of political and social pressure, and, second, under the pressure of professionalism and mimicry. The university has been taking similar actions as stated in the previous studies such as publishing papers in international top journals (Kim \& Nam, 2007), institutional merger (Aarrevaara, et. al., 2009) and so on. Higher education institutions in Mongolia have begun its changes not as early as other higher education institutions of other developed countries, and it was not fast enough to respond to the world competitive pressure of higher education rankings. Institutional changes taken place in the university was first pressured by the coercion dictated by the political social circumstances, that is, soviet regime; second, by the faculty members triggered by the professionalization; and third, by the mimicry modeling after successful higher education institution, which is an American higher education system.

Many previous studies document that institutional changes of higher education elsewhere are taking place in a similar manner at the institutional, policy and administrative level (Marginson, 2002; Proulx, 2007). These similar approaches to institutional changes are resulted from the competitive nature of world higher education rakings such as Times Higher Education and Academic Research University Rankings. Mongolian higher education is not left behind to build its higher education towards the level of a world class university.

Current study has its limits. It lacks enough quantitative data, though case study is more qualitative in nature. Further studies can use quantitative data to study recent changes preferably time-series analysis, and investment in higher education of Mongolia, and with its correlates of institutional factors.

\section{Acknowledgements}

I would like to express my sincere gratitude to the participants in this study. Their observations and shared experiences provided valuable sources of data for this study. Moreover, I would like to convey my thanks to the Division of Humanities of School of Arts and Sciences of the National University of Mongolia for the generous support to publish this paper.

\section{References}

Aarrevaara, T., Dobson, I., \& Elander, C. (2009). Brave new world. Higher Education Management and Policy, 21(2), 1-18. https://doi.org/10.1787/hemp-21-5ksj0twnffvl 
Arimoto, A. (2011). Japan: Effects of changing governance and management on the academic profession. In Changing governance and management in higher education (pp. 281-319). Springer, Dordrecht. https://doi.org/10.1007/978-94-007-1140-2_14

Balán, J. (2006). Reforming higher education in Latin America: Policy and practice. https://doi.org/10.1353/lar.2006.0017

Birnbaum, R. (2007). No world-class university left behind. International Higher Education, (47).

Boldbaatar, J., Baasanjav, Z., Gantsog, Ts., \& Davaa, S. (2002). A Historical Overview of the National University of Mongolia. Ulaanbaatar.

Byun, K., \& Kim, M. (2011). Shifting patterns of the government's policies for the internationalization of Korean higher education. Journal of Studies in International Education, 15(5), 467-486. https://doi.org/10.1177/1028315310375307

Clark, B. R. (1983). The higher education system. Berkeley. Cal.: University of California Press.

Corbin, J. M., \& Strauss, A. (1990). Grounded theory research: Procedures, canons, and evaluative criteria. Qualitative sociology, 13(1), 3-21. https://doi.org/10.1007/BF00988593

Dembereldorj, Z. (2018). Review on the Impact of World Higher Education Rankings: Institutional Competitive Competence and Institutional Competence. International Journal of Higher Education, 7(3), 25-35. https://doi.org/10.5430/ijhe.v7n3p25

DiMaggio, P. J., \& Powell, W. W. (1983). The iron cage revisited: Institutional isomorphism and collective rationality in organizational fields. American sociological review, 147-160. https://doi.org/10.2307/2095101

George, A. L., Bennett, A., Lynn-Jones, S. M., \& Miller, S. E. (2005). Case studies and theory development in the social sciences. MIT Press.

Hazelkorn, E. (2009). Rankings and the battle for world-class excellence. Higher education management and Policy, 21(1), 1-22. https://doi.org/10.1787/hemp-v21-art4-en

Jon, J. E., Lee, J. J., \& Byun, K. (2014). The emergence of a regional hub: Comparing international student choices and experiences in South Korea. Higher Education, 67(5), 691-710. https://doi.org/10.1007/s10734-013-9674-0

King, R. (2010). Policy internationalization, national variety and governance: global models and network power in higher education states. Higher Education, 60(6), 583-594. https://doi.org/10.1007/s10734-010-9317-7

Liguu, B. (1971). Mongolian People's Revolution and the New social class of Intelligence. Ulaanbaatar.

Marginson, S. (2002). Nation-building universities in a global environment: The case of Australia. Higher Education, 43(3), 409-428. https://doi.org/10.1023/A:1014691304966

Ngok, K., \& Guo, W. (2008). The quest for world class universities in China: Critical reflections. Policy Futures in Education, 6(5), 545-557. https://doi.org/10.2304/pfie.2008.6.5.545

Proulx, R. (2007). Higher education ranking and leagues tables: Lessons learned from benchmarking. Higher Education in Europe, 32(1), 71-82. https://doi.org/10.1080/03797720701618898

Purevdulam, G. (2005) Legal regulations of university administration. Doctoral dissertation. National University of Mongolia. Ulaanbaatar.

Shagdar, Sh. (2008). History of Mongolian education. Ulaanbaatar.

Sodnom, N. (2003). University of Mongolia: Multi-perspective historical notes. Ulaanbaatar.

Yin, R. (2003). K. (2003). Case study research: Design and methods. Sage Publications, Inc, 5, 11.

Yin, R. K. (2009). Case Study Research: Design and Methods (4th ed.). Thousand Oaks, CA: Sage Publications.

\section{Notes}

Note 1. Rector is the administrative position name for the President of the university. It was adopted during the Soviet Union period in Mongolian higher education system.

Note 2. Prorector is the administrative position of the vice - president at the university. The position name was adopted from the Soviet Union higher education system. 